\title{
Does Bacillus anthracis Lethal Toxin Directly Depress Myocardial Function? A Review of Clinical Cases and Preclinical Studies
}

\author{
Dante A. Suffredini ${ }^{1, *}$, Hanish Sampath-Kumar ${ }^{1}$, Yan Li ${ }^{1}$, Lernik Ohanjanian ${ }^{1}$, \\ Kenneth E. Remy ${ }^{2}$, Xizhong Cui ${ }^{1}$ and Peter Q. Eichacker ${ }^{1}$ \\ Received: 4 November 2015; Accepted: 7 December 2015; Published: 12 December 2015 \\ Academic Editor: Vernon Tesh \\ 1 Critical Care Medicine Department, Clinical Center, National Institutes of Health, Bethesda, MD 20892, \\ USA; hanishsampathkumar@gmail.com (H.S.-K.); yli3@cc.nih.gov (Y.L.); \\ lernik.ohanjanian@nih.gov (L.O.); CXizhong@cc.nih.gov (X.C.); PEichacker@cc.nih.gov (P.Q.E.) \\ 2 Division of Critical Care Medicine, Department of Pediatrics, Washington University School of Medicine, \\ St. Louis, MO 63110, USA; Remy_K@kids.wustl.edu \\ * Correspondence: dante.suffredini@nih.gov; Tel.: +1-301-496-9320; Fax: +1-301-402-1213
}

\begin{abstract}
The US outbreak of B.anthracis infection in 2001 and subsequent cases in the US and Europe demonstrate that anthrax is a continuing risk for the developed world. While several bacterial components contribute to the pathogenesis of B. anthracis, production of lethal toxin (LT) is strongly associated with the development of hypotension and lethality. However, the mechanisms underlying the cardiovascular instability LT produces are unclear. Some evidence suggests that LT causes shock by impairing the peripheral vasculature, effects consistent with the substantial extravasation of fluid in patients dying with $B$. anthracis. Other data suggests that LT directly depresses myocardial function. However a clinical correlate for this latter possibility is less evident since functional studies and post-mortem examination in patients demonstrate absent or minimal cardiac changes. The purposes of this review were to first present clinical studies of cardiac functional and histologic pathology with B. anthracis infection and to then examine in vivo, in vitro, and ex vivo preclinical studies of LT's myocardial effects. Together, these data suggest that it is unclear whether that LT directly depresses cardiac function. This question is important for the clinical management and development of new therapies for anthrax and efforts should continue to be made to answer it.
\end{abstract}

Keywords: Bacillus anthracis; anthrax; lethal and edema toxins; cardiovascular dysfunction; shock; treatment

\section{Introduction}

The development of shock in patients with Bacillus anthracis (B. anthracis or anthrax) infection appears associated with a particularly poor prognosis. In contrast to mortality rates of $40 \%$ to $50 \%$ with shock complicating other types of bacterial infection, in recent anthrax outbreaks in the US and Europe, mortality rates in patients with shock have been greater than $75 \%$ [1-4]. B. anthracis produces two toxins, lethal and edema toxins (LT and ET respectively), as well as other components (e.g., non-toxin proteases and cell wall components) which may contribute to its pathogenesis [5]. Of these components however, production of LT has been most strongly associated with the development of hypotension and subsequent lethality. Despite increasing insights into $\mathrm{LT}^{\prime}$ 's intracellular effects, the mechanisms underlying the cardiovascular instability it produces are unclear.

On the other hand, some experimental data have also suggested that LT produces shock by impairing the peripheral vasculature via either disruption of endothelial barrier or vascular smooth 
muscle function [6-10]. Such effects would be very consistent with the substantial extravasation of fluid and resistance to conventional hemodynamic support that has been noted to occur in patients and animals dying with $B$. anthracis infection $[1,2,11,12]$. On the other hand, some experimental data has also suggested that LT produces shock by directly depressing myocardial systolic and/or diastolic function [13-17]. However a clinical correlate to this possibility is less evident. Although data regarding cardiac function in patients with B. anthracis are limited, there are several striking examples of patients dying with anthrax associated shock but in whom echocardiographic and even pulmonary arterial catheter measures of myocardial function close to the time of death were reported to be normal $[18,19]$. Also, while LT has been reported to depress myocardial function in animal models, these observations have sometimes been based on calculated reductions in cardiac output (CO) or left ventricular ejection fraction (LVEF) measured with echocardiography $[10,13,20]$. These studies can be difficult to interpret since the influence of preload or afterload changes on heart volumes, CO or LVEF have typically not been accounted for.

Given the likely important contribution LT makes to the development of shock during B. anthracis infection, a clearer understanding of whether it does in fact directly depress myocardial function has important clinical and research implications. First, it would emphasize the need for practitioners to directly monitor myocardial function in patients with invasive anthrax infection and cardiovascular instability and to consider the early use of vasoactive agents with strong inotropic effects. Second, it would highlight the need for research directed at identifying mechanisms underlying LT induced myocardial defects and the agents best able to correct those. After a short description of LT and its intracellular actions, the purpose of the present review is to first examine whether clinical data implicates cardiac dysfunction in the pathogenesis of B. anthracis infection and to then summarize in vivo, in vitro, and ex vivo preclinical data investigating LT's potential effects on myocardial function.

\section{Lethal Toxin and Its Intracellular Actions}

Lethal toxin is a binary type toxin comprised of protective antigen (PA), the component necessary for toxin uptake by host cells, and lethal factor (LF), the toxic component $[9,21]$. During infection, both $\mathrm{PA}$ and LF are released into the circulation. A PA protomer $\left(\mathrm{PA}_{83}\right)$ binds to one of at least two receptors on host cells; tumor endothelial marker-8 (TEM-8) or capillary morphogenesis gene-2 (CMG2), also termed anthrax toxin receptors 1 or 2 (ANTR-1 or ANTR-2), respectively. Both receptors are widely distributed in host tissues including the heart and blood vessels although some data suggests that CMG2 binding plays a predominant role in LT's effects during infection [9]. The $\mathrm{PA}_{83}$ protomer then undergoes furin cleavage, and the remaining bound monomer $\left(\mathrm{PA}_{63}\right)$ forms heptamers or octamers that up to three or four LF molecules (or edema factor [EF] molecules, the toxic moiety of ET) can bind to. This complex then undergoes endocytosis and as the endosomal pH decreases, the LF (and EF) molecules are released into the host cell's cytosol where they can act.

Lethal factor is a metalloprotease which has two primary actions: it cleaves mitogen activated protein kinase kinase (MAPKK) pathways 1 to 4, 6 and 7, thus disrupting key host stress kinase pathways (ERK 1 and 2, p38 and JNK 1) and; it activates the host inflammasome NLRP3, resulting in upregulation of caspase-1 and the production of IL-1 and IL-12 [22,23]. Evidence suggests that both of these actions have the potential to produce relatively acute and direct myocardial injury and dysfunction [24,25].

\section{Effects of B. Anthracis Infection on the Heart in Clinical Studies}

As noted above, studies investigating myocardial function in patients with $B$. anthracis are very limited. Furthermore, any abnormalities that have been reported cannot be attributed to LT alone given the multiple other bacterial components associated with this bacterium that could alter the heart [5]. Other types of gram-positive bacterial infection have been associated with myocardial depression in the absence of LT [26]. It is still worthwhile though to consider what is known about 
the myocardial effects of $B$. anthracis infection in patients as a basis for considering what LT might contribute to. In this context, clinical data are primarily comprised of histopathology findings from patients dying with anthrax infection and of functional studies available in a small number of isolated case reports.

The largest group of anthrax cases for which pathological data are available comes from the outbreak of inhalational infection in Sverdlovsk, Russia in 1979, which affected at least 94 people, 64 of whom died [11,12]. This outbreak resulted from the inadvertent release of anthrax spores from a bioweapons factory. Quantitative histological examination of 41 autopsy cases from this outbreak was noteworthy for extensive bacterial involvement of the mediastinum and mediastinal lymph nodes with associated tissue edema, hemorrhage, fibrin deposition, and vasculitis, and with spread of these changes to the intestines and central nervous system (CNS) in some cases. Large pleural effusions and retrograde lymphatic spread of bacteria producing pneumonia were observed to have likely resulted in respiratory compromise. Investigators speculated that much of the changes noted were related to initial foci of bacteria releasing LT and ET, which in turn produced loss of endothelial integrity, edema formation, hemorrhage, and subsequently apoptotic cell death. Despite extensive changes in several organs though, examination of heart tissue in 25 patients demonstrated bacteria in only nine specimens. Furthermore, there were no specific cardiac microscopic findings noted, with exception of a few cases showing myocyte hypereosinophilia and rare focal-contraction band necrosis attributed to agonal hypotension and hypoxemia.

Another group of clinical autopsies (five) or tissue samples (three lung biopsies) available for review comes from the outbreak of inhalational anthrax affecting 11 patients in the United States in 2001 [1,27]. This outbreak resulted from the dissemination of anthrax contaminated letters. While tissue examination was reported individually from several of these cases, a systematic analysis was also performed of all eight cases. This analysis reported that the major pathological and histopathological findings came from immunohistochemistry (IHC) staining which showed B. anthracis cell wall and capsule fragments in mediastinal lymph nodes, soft tissue, and pleura and in the blood vessels or sinusoids of lung, liver, spleen, and intestines. Notably, findings related to the heart in patients with autopsies were not specifically recorded, other than that rare bacteria were present in coronary vessels. Individual reports from these five cases concentrated on mediastinal (lymph nodes and soft tissue), lung, intestinal and CNS tissue examination and none reported findings specifically regarding the heart or myocardium [28-31].

In three autopsy cases reported from an outbreak of $B$. anthracis among wool workers, there was no mention of abnormal myocardial changes on microscopic examination in two, while moderate sub-endocardial hemorrhage was noted in one [32]. In a review of 33 autopsy cases, while microscopic changes were described in the lung, gastrointestinal tract, lymph nodes, spleen, liver, and kidney, there was no report of abnormal findings on heart examination [33].

Thus in these reports, there appeared to be limited histologic evidence of myocardial injury in patients dying with B. anthracis infection. However, this does not exclude the possibility that electron microscopy or other histologic methods might not have shown evidence of myocardial involvement.

Functional cardiac studies from patients with $B$. anthracis infection are very limited. Over the past 15 years there have been approximately 80 cases of inhalational, gastrointestinal, or injectional anthrax (i.e., the three forms of infection associated with high mortality rates) reported to have occurred in the US or Europe [1,2,34-38]. Of these, 48 appear to have actually been noted in the literature either in individual case reports or case series. Among these reports, descriptions of functional cardiac studies have been provided in only 11 patients. The most detailed study was of a 61 year old woman, who presented during the 2001 B. anthracis outbreak with respiratory distress with bilateral pleural effusions, peri-hilar infiltrates and a widened mediastinum on chest radiograph [18]. Echocardiogram at presentation showed normal left ventricular function and wall motion, slight aortic regurgitation, a small pericardial effusion and an aneurysm of the ascending aorta. EKG showed sinus tachycardia but was otherwise normal and a troponin level was negative. 
Although treated initially with furosemide for presumed heart failure, the patient's respiratory and hemodynamic status rapidly worsened and she was intubated and mechanically ventilated. A pulmonary artery catheter was placed which showed a right atrial pressure of $4 \mathrm{mmHg}$ (reference range 0-6 $\mathrm{mmHg}$ ), right ventricular pressure of $17 / 5 \mathrm{mmHg}$ (reference range $20-30 / 5-15 \mathrm{mmHg}$ ) and a pulmonary artery pressure of $20 / 10 \mathrm{mmHg}$ (reference range of $20-30 / 5-15 \mathrm{mmHg}$ ). Pulmonary artery occlusion pressure (PAOP) was unobtainable and cardiac output was not reported. The patient then received volume resuscitation for hemodynamic instability and vasopressors were ultimately required. After initial testing, differential diagnosis included dissecting aortic aneurysm, severe community acquired pneumonia, vasculitis, or anthrax, but not heart failure. Blood cultures from admission grew $B$. anthracis. Echocardiography on day 2 showed an increase in the size of the pericardial effusion. The patient's respiratory status continued to worsen and a repeat echocardiogram on day 3 showed further increase in the pericardial effusion and mild to moderate right atrial and ventricular collapse during diastole. Cardiac index was $2.6 \mathrm{~L} / \mathrm{min} / \mathrm{m}^{2}$ (reference range 2.4 to $4.0 \mathrm{~L} / \mathrm{min} / \mathrm{m}^{2}$ ), systemic vascular resistance was 1131 dynes. $\mathrm{s} \cdot \mathrm{m}^{2} / \mathrm{cm}^{5}$ (reference range 900-1400 dynes $\mathrm{s} \cdot \mathrm{m}^{2} / \mathrm{cm}^{5}$ ) and a pulmonary capillary wedge pressure of $13 \mathrm{mmHg}$ (reference range 6-12 $\mathrm{mmHg}$ ) with no evidence of equalization of pressures. A follow-up echocardiogram $5 \mathrm{~h}$ later showed persistent collapse of the right atrium and ventricle concerning for tamponade. An attempted pericardiocentesis was unsuccessful and the patient expired. Autopsy showed a hemorrhagic pericardial effusion.

Other clinical reports of cardiac assessment in anthrax patients provide less information. Echocardiography was performed close to the time of admission in a 44 year old male patient subsequently found to have inhalational anthrax related to infected animal hides and who presented with two to three days of fever, respiratory symptoms, and evidence of pneumonia with a loculated pleural effusion [35]. Echocardiography showed a slightly dilated and mild to moderately hypertrophied left ventricle with a mildly hypokinetic apex, contractility at the lower limits of normal for the rest of the ventricle and a small pericardial effusion (personal communication with author). This patient developed progressive respiratory distress related to his pulmonary disease and hemodynamic compromise requiring mechanical ventilation and circulatory support but additional echocardiographic findings were not reported. In a 61 year old man with inhalational anthrax of unclear origin who presented with progressive respiratory failure requiring mechanical ventilation but who remained hemodynamically stable, an echocardiogram on day six of hospitalization showed left ventricular hypertrophy, mildly decreased LVEF (40\%), no wall motion abnormality, an estimated pulmonary artery systolic pressure of $17 \mathrm{mmHg}$, probable decreased right ventricular function and no pericardial effusion (personal communication with author) [38]. A cardiac troponin I (cTnI) level close to the time of the echocardiogram was $0.025 \mathrm{ng} / \mathrm{mL}$ (reference value $<0.034 \mathrm{ng} / \mathrm{mL}$ ). The patient survived but no follow up echocardiogram was performed. A 55 year old man with severe injectional anthrax involving his thigh and peritoneum developed fulminant septic shock that progressed to cardiac arrest and was resuscitated after $12 \mathrm{~min}$ of CPR. A transesophageal echocardiogram performed on day 2 of hospitalization, after his cardiac arrest and while on high dose vasopressors and with systemic acidosis, was reported as normal [19]. This patient died on day 4 of hospitalization with progressive multi-organ failure but no subsequent echocardiogram was provided. A 24 year old woman presenting with nine days of progressive fatigue, fever, abdominal pain, and shock was later found to have gastrointestinal anthrax. An echocardiogram completed at admission was reportedly normal [37]. Finally, a survey of physicians that cared for 27 patients with injectional anthrax investigated multiple clinical end points pertaining to physical and laboratory findings, management and outcome. In this study, four patients reportedly had echocardiography while one patient had lithium dilution measures and another pulse contour cardiac output analysis [2]. Of these patients, three were noted to have normal echocardiograms, while the remaining three, all non-survivors, were reported to have abnormal findings with their respective tests, but actual data were not recorded. 
Other case reports of clinical anthrax have not included any functional or histopathologic cardiac data $[27,39-44]$.

Table 1 summarizes cardiac findings from the clinical studies. Overall, these studies do not provide a clear picture as to whether $B$. anthracis infection is or is not associated with myocardial depression. It is unknown whether the limited data available regarding functional cardiac studies in clinical reports is the result of incomplete testing or because the results of such testing were unremarkable and not thought relevant for reporting.

Table 1. Summary of cardiac findings or the absence of any reported findings from clinical anthrax studies.

\begin{tabular}{|c|c|c|c|}
\hline Publication & Number of Patients & $\begin{array}{l}\text { Type of Anthrax } \\
\text { Infection }\end{array}$ & $\begin{array}{l}\text { Clinical or Histopathological } \\
\text { Cardiac Findings }\end{array}$ \\
\hline Albrink et al. 1960 [32] & 3 & Inhalational & $\begin{array}{l}\text { Moderate subendocardial } \\
\text { hemorrhage into myocardium of } \\
\text { left ventricle noted at autopsy }\end{array}$ \\
\hline $\begin{array}{l}\text { Abramova et al. } 1993 \text { [11] } \\
\text { Grinberg et al. } 2001 \text { [12] }\end{array}$ & 42 & Inhalational & $\begin{array}{l}\text { No specific cardiac } \\
\text { histopathological findings were } \\
\text { noted. However, occasional cases } \\
\text { showed myocyte } \\
\text { hypereosinophilia and rare focal } \\
\text { contraction band necrosis } \\
\text { attributed to agonal hypotension } \\
\text { and hypoxemia }\end{array}$ \\
\hline Mayer et al. 2001 [44] & 2 & Inhalational & $\begin{array}{l}\text { No functional cardiac } \\
\text { assessment completed }\end{array}$ \\
\hline Borio et al. 2001 [29] & 2 & Inhalational & $\begin{array}{l}\text { ECG showing atrial fibrillation, } \\
\text { no other specific findings noted }\end{array}$ \\
\hline Jernigan et al. 2001 [1] & $10 *$ & Inhalational & $\begin{array}{l}\text { ECG showing atrial fibrillation } \\
\text { noted in one of the four patients } \\
\text { not reported as isolated cases }\end{array}$ \\
\hline Bush et al. 2001 [28] & 1 & Inhalational & $\begin{array}{l}\text { No gross cardiac abnormalities on } \\
\text { autopsy found }\end{array}$ \\
\hline Barakat et al. 2002 [31] & 1 & Inhalational & $\begin{array}{l}\text { No functional cardiac } \\
\text { assessment completed }\end{array}$ \\
\hline Mina et al. 2002 [18] & 1 & Inhalational & $\begin{array}{l}\text { Echocardiogram showed normal } \\
\text { LV function at presentation with } \\
\text { small pericardial effusion that } \\
\text { enlarged and progressed to } \\
\text { tamponade. Pulmonary artery } \\
\text { catheterization also completed } \\
\text { (see Section 3) }\end{array}$ \\
\hline Guarner et al. 2003 [27] & $11 * *$ & Inhalational & $\begin{array}{l}\text { No specific cardiac } \\
\text { histopathological } \\
\text { abnormalities noted }\end{array}$ \\
\hline Tabei et al. 2004 [33] & 33 & $\begin{array}{l}\text { Cutaneous, } \\
\text { Inhalational, and } \\
\text { Gastrointestinal }\end{array}$ & $\begin{array}{l}\text { No specific cardiac } \\
\text { histopathological } \\
\text { abnormalities noted }\end{array}$ \\
\hline $\begin{array}{l}\text { Babamahmoodi et al. } 2005 \\
\text { [39] }\end{array}$ & 3 & Gastrointestinal & $\begin{array}{l}\text { No functional cardiac } \\
\text { abnormalities noted }\end{array}$ \\
\hline Walsh et al. 2007 [35] & 1 & Inhalational & $\begin{array}{l}\text { Echocardiogram showing } \\
\text { minimal pericardial effusion }\end{array}$ \\
\hline Klempner et al. 2010 [37] & 1 & Gastrointestinal & $\begin{array}{l}\text { Transthoracic echocardiogram } \\
\text { showed a normal ejection } \\
\text { fraction, no valvular vegetations } \\
\text { and findings consistent with right } \\
\text { atrial volume overload, and right } \\
\text { ventricular systolic hypertension }\end{array}$ \\
\hline Doganay et al. 2010 [40] & 22 & Cutaneous & $\begin{array}{l}\text { No functional cardiac } \\
\text { abnormalities noted }\end{array}$ \\
\hline Popescu et al. 2011 [41] & 2 & Cutaneous & $\begin{array}{l}\text { No functional cardiac } \\
\text { abnormalities noted }\end{array}$ \\
\hline
\end{tabular}


Table 1. Cont.

\begin{tabular}{cccl}
\hline Publication & Number of Patients & $\begin{array}{c}\text { Type of Anthrax } \\
\text { Infection }\end{array}$ & $\begin{array}{l}\text { Clinical or Histopathological } \\
\text { Cardiac Findings }\end{array}$ \\
\hline Powell et al. 2011 [42] & 1 & Injectional & $\begin{array}{l}\text { No functional cardiac } \\
\text { abnormalities noted }\end{array}$ \\
\hline Gruno et al. 2012 [43] & 3 & Injectional & $\begin{array}{l}\text { No functional cardiac } \\
\text { abnormalities noted }\end{array}$ \\
\hline Russel et al. 2013 [19] & Injectional & $\begin{array}{l}\text { Transesophageal echocardiogram } \\
\text { reported normal in setting of } \\
\text { fulminant septic shock }\end{array}$ \\
\hline Booth et al. 2014 [2] & Injectional & $\begin{array}{l}\text { Of nine patients reported, three } \\
\text { had dysfunction based on } \\
\text { echocardiography, lithium } \\
\text { dilution or pulse contour cardiac } \\
\text { outputs, and one had an elevated } \\
\text { troponin. Other patients had no } \\
\text { evidence of abnormal cardiac } \\
\text { function (see section 3) }\end{array}$ \\
\hline Sprenkle et al. 2014 [38] & & $\begin{array}{l}\text { Echocardiogram showed left } \\
\text { ventricular hypertrophy with EF } \\
\text { of 40\%, normal estimated } \\
\text { pulmonary artery pressure, } \\
\text { probable decreased right } \\
\text { ventricular function and no } \\
\text { pericardial effusion }\end{array}$ \\
\hline
\end{tabular}

* This review included six other patients in this table described as isolated cases including reports by Mayer, Borio, Bush and Mina; ${ }^{* *}$ This review included patients in this table described in case reports by Jernigan and Barakat.

\section{Effects of LT on the Heart in in vivo, in vitro and ex vivo Studies}

Following the identification of LT (and ET) by Smith et al. in 1955 and up until the early 1970s, there were multiple studies performed by several groups employing small and large animal models examining LT's physiologic effects, including its cardiopulmonary ones [45,46]. While some of these studies did examine myocardial histology, and many measured blood pressure and heart rate, there were no studies that employed techniques permitting an investigation of the potential direct myocardial effects of LT. In these investigations, most of which employed a LT challenge administered as an intravenous (i.v.) bolus, the predominant cardiopulmonary changes noted were disruption of the pulmonary arterial endothelium with attendant edema and hemorrhage $[47,48]$. Hypotension did not occur until very close to the time of death in these models and was attributed primarily to already evident pulmonary dysfunction. Following these early studies, there was limited research examining the cardiovascular effects of LT until the outbreak of infection in the US in 2001. Notable in that outbreak in which patients received aggressive ICU support when needed, and at odds with earlier conclusions regarding LT's potential cardiovascular effects, was that shock occurred well before death in some non-survivors and was not the result of respiratory failure [1]. However, as described above, shock in patients appeared associated with a particularly poor outcome when compared to other types of bacteria.

Following the 2001 outbreak, there was renewed interest in investigating the cardiovascular effects of LT in both in vivo and in vitro models. One of the first studies to be published in this regard did not include hemodynamic measures but employed comprehensive histologic examination in combination with biomarker analysis in mice challenged with LT [49]. This study concluded that LT produced non-inflammatory hypoxic tissue injury consistent with a state of hypoperfusion that was tumor necrosis factor $\alpha(\mathrm{TNF} \alpha)$ independent. Histology demonstrated minimal myocardial coagulative necrosis with mild cardiac dilation at $48 \mathrm{~h}$ in a few animals. However, creatinine phosphokinase measures were notably elevated to high levels in some animals. Our group, employing $24 \mathrm{~h} \mathrm{LT}$ infusions in rats to better simulate toxin release during infection and measuring blood pressure continuously with indwelling catheters in awake animals, demonstrated that LT 
produced gradual reductions in blood pressure that were greater in non-survivors than survivors [50]. Lethal toxin did not alter oxygenation or lung or myocardial histology measured on light microscopy. The development of shock with LT was also not associated with the systemic inflammatory response a comparably lethal dose of lipopolysaccharide produced. However, neither of these studies directly examined the effects of LT on myocardial function.

The initial investigations reporting that LT might produce direct myocardial depression were performed by a group employing echocardiography in Sprague-Dawley rats. In one study, animals were challenged with LT as an i.v. bolus [13]. Although the LT dose employed was designed to produce an approximate $50 \%$ lethality rate, mean arterial blood pressure (MAP, measured telemetrically) appeared to decrease markedly over a 6 to $8 \mathrm{~h}$ period to less than $30 \mathrm{mmHg}$ and subsequent measures were not reported. Echocardiography performed from 0 to $2 \mathrm{~h}$, demonstrated that compared to control animals, LT produced significant increases in both left ventricular systolic and diastolic areas (LVAs and LVAd respectively) and in the velocity of propagation (Vp), a surrogate measure of left ventricular compliance. Left ventricular ejection fractions (LVEF) were reportedly decreased with LT, but calculated values were not provided. It was concluded that LT had induced acute myocardial dysfunction comparable to fulminant myocarditis and manifested by marked increases in ventricular compliance. However, the rapid and marked reductions in blood pressure occurring in the model confound the echocardiographic findings since it is unclear to what degree they contributed to versus were the result of the cardiac changes noted. In a subsequent study using a similar LT challenge (i.v. bolus), animals were sacrificed 2 to $5 \mathrm{~h}$ after LT and tissue was taken for histological analysis [51]. Light and electron microscopic examination of lung tissue from LT challenged animals demonstrated extensive extravascular fluid and fibrin deposition consistent with pulmonary edema. Unfortunately no analysis was provided of heart tissue and so it is unknown whether there was a histologic basis either on light or electron microscopy for the functional myocardial changes the investigators had previously reported on in this same model. However, examination of liver, trachea, esophagus, kidney, urinary bladder, thyroid, parathyroid, adrenals, pancreas, pituitary, brain, and bone marrow did not show changes. In another in vivo study reported by this group, rats had serial blood pressure via non-invasive tail measurements and echocardiography measures at baseline before and from 12 to $48 \mathrm{~h}$ after intraperitoneal (i.p.) LT challenge [52]. In this study, LT administration was reported to reduce Vp (as opposed to the increases previously noted), to increase LVAs (but not LVAd) and reduce LVEF. Heart-rate-corrected-velocity of circumferential fiber shortening (VCFC) was also decreased with LT and was reported to reflect a reduction in left ventricular contractility. Based in part on their findings with echocardiography in the rat model, as described next, investigators from this group collaborating with others, did additional in vivo and in vitro studies to understand how LT might affect heart function at the cardiomyocyte level.

In one series of studies using cardiomyocytes isolated from normal mice and treated with LT or from mice challenged $18 \mathrm{~h}$ previously with intraperitoneal (i.p.) LT, the investigators reported that LT inhibited cardiomyocyte peak shortening (PS) and the maximal velocity of shortening and re-lengthening $( \pm \mathrm{dL} / \mathrm{dt})$, and increased the time to peak shortening (TPS) and time to $90 \%$ re-lengthening $\left(\mathrm{TR}_{90}\right)[15,53,54]$. These changes were associated with an inhibitory effect of LT on $\mathrm{Ca}^{2+}$ transients within the cardiomyocytes, manifested primarily by a prolongation in $\mathrm{Ca}^{2+}$ decay. Experiments with either aponycin, an NADPH oxidase inhibitor or with catalase over-expressing mice, suggested that the inhibitory effects of LT on cardiomyocyte function was in part related to the production of superoxide and reactive oxygen species (ROS). Other experiments suggested that these or additional actions by LT produced cardiomyocyte depression via mechanisms involving; interference with the $\mathrm{Ca}^{2+}$ regulatory proteins SERCA2a and phospholamban (PLB); stimulation of autophagy and to a lesser extent endoplasmic reticulum (ER) stress; and the production of mitochondrial membrane or ubiquitin and proteasome defects. However these effects were not always consistent when the methods of cardiomyocyte exposure to LT were compared. For example, 
while measures $2 \mathrm{~h}$ after in vitro LT exposure showed up and down regulation of the $\mathrm{Ca}^{2+}$ regulatory proteins SERCA2a and phospholamban (PLB) respectively, these proteins were not altered when measured $18 \mathrm{~h}$ after in vivo i.p. LT exposure. Other experiments in this series of studies in knockout mice suggested that the effects of i.p. LT challenge on cardiomyocyte function were mediated in part by toll-like receptor-4 (TLR-4). Echocardiography in this experiment showed that while LT in wild type mice (WT) reduced left ventricular end diastolic dimensions (LVEDD) and left ventricular end systolic dimensions (LVESD) and calculated fractional shortening and cardiac output, these changes were smaller in TLR-4 knockout animals.

In another study by members of this group, serial echocardiographic measures in Sprague-Dawley rats challenged with a minimally lethal i.v. LT bolus demonstrated very early (2 to $4 \mathrm{~h}$ after challenge) evidence of diastolic heart failure with pulmonary artery regurgitation and left atrial dilation, when compared to baseline measurements [16]. Left ventricular ejection fraction was unchanged with LT challenge in this model. Non-challenged animals serving to control for the effects of serial echocardiography and anesthetics (baseline, 2, 4, 8, and $24 \mathrm{~h}$ after challenge) were not presented. In data that were compared to a control, LT challenge was noted to increase intracellular $\mathrm{Ca}^{2+}\left(\mathrm{Ca}^{2+}{ }_{i}\right)$, an effect that could result in diastolic dysfunction. Consistent with the known effect of LT on interference with MEK and activation of MAPKs, LT challenge was found to inhibit of MEK7 and JNK1 activity resulting in downstream activation of protein phosphase, dephosphorylation of PLB, and interference with SERCA2a regulated $\mathrm{Ca}^{2+}$ uptake by the sarcoplasmic reticulum. The investigators in this study suggested that the early diastolic dysfunction that was observed with LT may have a clinical correlate in the pleural and pericardial effusions and pulmonary edema sometimes noted in patients with $B$. anthracis infection.

While this series of studies is informative, limited data was presented linking the mechanisms speculated to underlie LT's depressant effects, to the echocardiographic changes (increased or decreased Vp and increased LVAs alone or in combination with increased LVAd) or to the hypotension and lethal effects, LT was originally reported to produce [13,15,52-55]. While survival was modestly prolonged with an i.p. LT challenge in catalase overexpressing mice compared to wild type animals, these changes were not reported to be significant and no measures of in vivo cardiac function were described. Also, in the echocardiography data that was presented in the studies comparing TLR-4 knockout and WT mice, LT was associated with decreases in LVEDD and LVESD, and not the increases (either in both or only the latter) that would have been expected based on the original rat experiments showing increases in LVAd and LVAs [13,52]. Overall, these studies certainly suggest that LT may have important myocardial effects. However they also highlight how the effects of challenge with biological agents in animal models may vary based on the method of challenge and the model employed for study.

Studies by another group have also suggested that direct myocardial depression has a role in LT associated lethality [49]. An initial study noted above in mice challenged with i.p. or i.v. LT, while not showing marked myocardial changes on histology, noted significantly increased creatine phosphokinase levels in animals consistent with myocardial injury. In a subsequent study, this group measured three more selective markers of cardiac injury including myoglobin, cardiac troponin-I (cTnI) and heart type fatty acid binding protein (H-FABP) for up to $120 \mathrm{~h}$ after lethal i.p. LT challenge in C57BL/6J mice [14]. They found substantial increases in all three of these markers within the first $15 \mathrm{~h}$ after toxin challenge that persisted for up to $48 \mathrm{~h}$. As opposed to light microscopy of heart tissue which showed little change with LT in the model, electron microscopy showed endothelial necrosis, inter-fiber edema with cell debris, altered endothelial junctions, and fragmented myofilaments. Despite these biochemical and ultrastructural changes though, echocardiography of animals $24 \mathrm{~h}$ after LT challenge only showed a trend in reduced LVEF. However, the striking and rapid increases in cardiac-selective enzymes with LT in the study suggested that the heart might be an early target of LT in this mouse model. This possibility was explored further in studies employing mice engineered to either lack or to over-express CMG2 in selected tissues [10]. In these elegant studies in mice 
challenged with i.p. LT, selective deletion of CMG2 in cardiac and vascular smooth muscle tissue together was highly protective and deletion in cardiac tissue alone was still protective but less so. CMG2 deletion in endothelial tissue alone was not protective. Consistent with this, increases in cTnI and decreases in LVEF with LT challenge were reduced or not evident in mice lacking CMG2 expression in cardiac tissue alone or and in cardiac and vascular smooth muscle tissue together. However, at higher LT doses, mice lacking CMG2 in all three cell types were more resistant to LT than cells lacking CMG2 in only cardiac and vascular smooth muscle cells. These results support the possibility that in this mouse model, LT's effects on cardiac, vascular smooth muscle and endothelial cells all contribute to the toxin's pathogenic effects, although endothelial cells may only contribute when LT levels are very high. Notably however, while mice lacking CMG2 in all three cell types together were resistant to B. anthracis spore challenge, ones lacking it in endothelial cells alone, were not.

Another group studied serial electrocardiograms (ECG), cTnI and echocardiography measures up to $72 \mathrm{~h}$ after low or high doses of LT challenge in Dutch belted rabbits [20]. Some animals were also sacrificed at $72 \mathrm{~h}$ for histology studies. High but not low LT doses were associated with reductions in MAP first evident at $36 \mathrm{~h}$. Both low and high LT doses were associated with increases in cTnI levels at 48 and $72 \mathrm{~h}$ although ECGs were unchanged. Although quantitative measures were not provided, light microscopy studies at $72 \mathrm{~h}$ were described as showing mild myodegeneration and subacute inflammation with histiocytes, mononuclear cells, and heterophils present in low dose animals and acute, multifocal cardiac myocyte necrosis with and without mineralization in the ventricles and septum in high dose animals. Despite these increases in cTnI and histologic changes, left ventricular internal diastolic and systolic diameters on echocardiography did not differ from controls in high dose animals at $48 \mathrm{~h}$ (when cTnI levels were highest).

These studies of LT's effects on myocardial function in in vivo mouse and rat models, while informative, did not examine this function using methods that controlled for the potential preload and afterload effects of LT. These studies have also not typically measured pulmonary function to determine whether respiratory failure itself might have contributed to myocardial changes with LT. However, a small number of studies have attempted to address these confounding variables.

In a review of their early work, investigators that first reported the effects of LT challenge on echocardiography measures in the rat described data from six canines with indwelling left ventricular pressure-volume loop catheters that were observed for up to $96 \mathrm{~h}$ after a lethal dose of LT (four animals) or control (two animals) challenge [55-57]. Using these direct measures, the investigators noted that a lethal iv LT challenge was associated with progressive increases in end-diastolic pressures and time of relaxation and a rightward shift of pressure-volume curves with decreases in contractility, left ventricular ejection fraction, and stroke volume, together suggesting the presence of both systolic and diastolic dysfunction. Isolated cardiomyocyte contractile function was determined at the time of the animals' death or sacrifice and showed a $46 \%$ reduction in cell contraction and relaxation in LT challenged animals. This study appears to be a highly informative one but unfortunately its findings have only been published in abstract and review form. Much data such as the course of blood pressure changes occurring in the model would be of considerable value to better assess the myocardial changes described. Also, while this group had reported that LT caused lung injury in the rat, pulmonary findings were not described in this canine report [51]. Therefore, whether pulmonary dysfunction (e.g., hypoxia) contributed to the myocardial changes noted is unclear. 

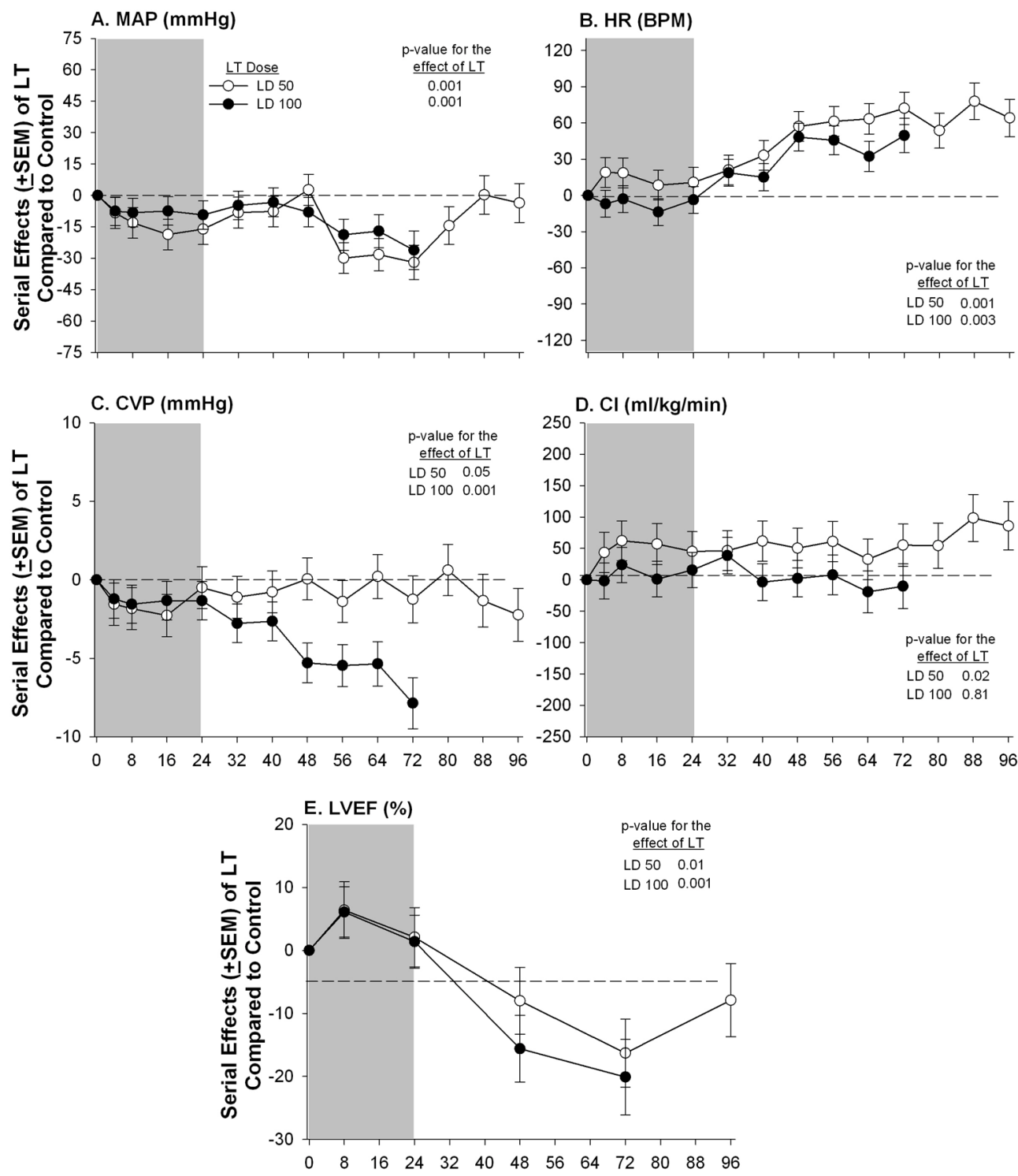

Time (h) Following the Start of a $24 \mathrm{~h}$ Lethal Toxin Infusion

Figure 1. Serial mean effects ( \pm SEMs) of $24 \mathrm{~h}$ infusions (shaded areas) of low (LD50) or high (LD100) doses of lethal toxin (LT) compared to protective antigen alone (controls) on changes from baseline in mean arterial pressure (MAP, panel A), heart rate (HR, panel B), central venous pressure (CVP, panel C), cardiac index (CI, panel D) and left ventricular ejection fraction (LVEF, panel E). The $p$-values shown are for the effects of LT compared to control. Increases or decreases with LT (compared to controls) are indicated by symbols above or below the dashed horizontal no-effect line respectively.

We have examined the effects of LT on myocardial function while attempting to account for its possible preload, afterload, and pulmonary effects, both in canines with indwelling systemic and pulmonary arterial catheters and in isolated rat hearts perfused under constant pressure. In canine studies, sedated and mechanically ventilated animals were challenged with $24 \mathrm{~h} \mathrm{LT}$ infusions and serial cardiopulmonary measures were obtained for up to $96 \mathrm{~h} \mathrm{[17].} \mathrm{Compared} \mathrm{to} \mathrm{controls,} \mathrm{both} \mathrm{lower}$ LT doses (50\% lethal) and higher doses (100\% lethal), produced progressive hypotension, increases in heart rate, and reductions in central venous pressure (CVP). Arterial oxygenation did not decrease with either low or high doses of LT throughout the $96 \mathrm{~h}$ study period. While neither LT dose altered pulmonary artery occlusion pressure (PAOP), both produced reductions in LVEF first evident $48 \mathrm{~h}$ after the initiation of toxin infusion (Figure 1). 
Cardiac index did not decrease with either toxin dose possibly because HR increased. On the one hand, decreases in LVEF in the face of unchanged PAOP and the absence of arterial hypoxemia, suggested that LT had potentially depressed myocardial function directly. However, it was also noted that daily normal saline volume loads $(40 \mathrm{~mL} / \mathrm{kg}$ over $40 \mathrm{~min}$ ) were associated with increased LVEF in animals challenged with high dose LT. This latter finding in combination with the low CVP levels measured with both toxin doses raised the possibility that changes in preload with LT may have contributed in part to the reduced LVEF. In the same LT challenged canine model, compared to no hemodynamic support (fluid and vasopressor therapy titrated to PAOP and MAP respectively) or hemodynamic support alone, hemodynamic support with a PA directed monoclonal antibody increased both CVP, LVEF, MAP, and survival [58].
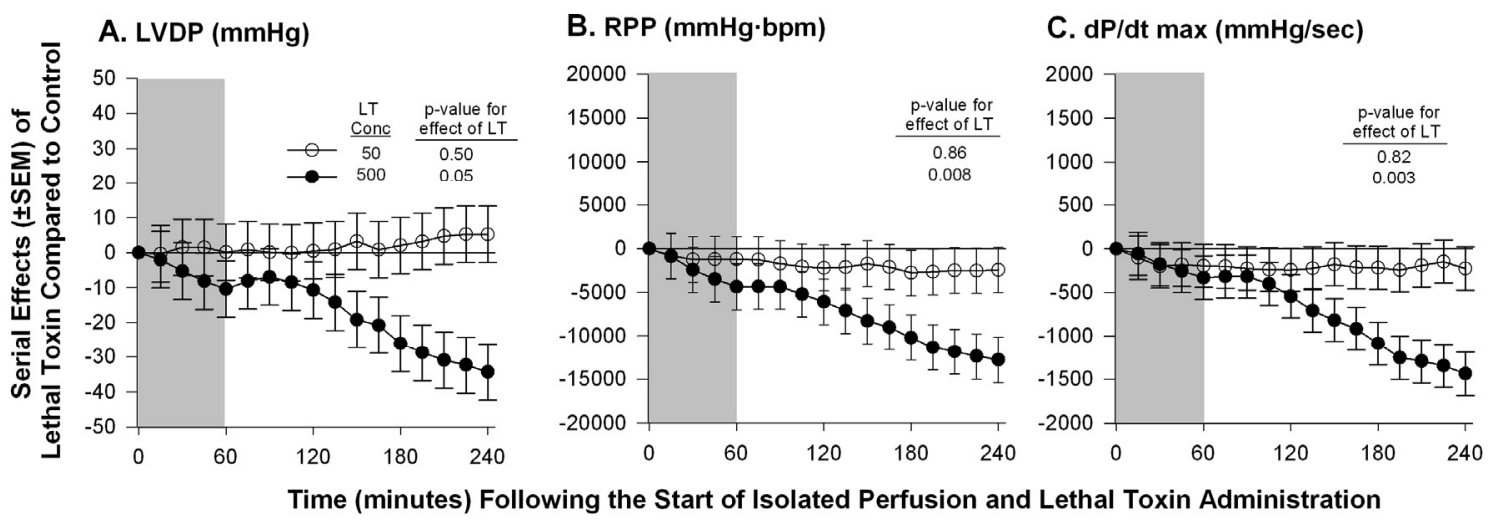

Figure 2. Serial mean effects ( \pm SEMs) of two concentrations of lethal toxin (LT, 50 or $500 \mathrm{ng} / \mathrm{mL}$ ) compared with protective antigen alone (controls) administered to isolated perfused hearts excised from healthy animals on left ventricular developed pressure (LVDP, panel A), rate pressure product (RPP, panel B) and rate of change in LV pressure during contraction ( $\mathrm{dP} / \mathrm{dt}$ max, panel $\mathrm{C})$. The shaded area represents the time of LT or control administration. The $p$-values shown are for the effect of LT versus control. Increases or decreases with LT (compared to controls) are indicated by symbols above or below the dashed horizontal no-effect line respectively. The LT concentration of $50 \mathrm{ng} / \mathrm{mL}$ was comparable to a dose previously shown to produce a $50 \%$ lethality rate in in vivo experiments. Although the concentration of $500 \mathrm{ng} / \mathrm{mL}$ did depress myocardial function, this represented a dose 10-fold greater than one producing lethality in vivo.

Therefore, to further examine the myocardial effects of LT in a system free of preload and afterload effects, we isolated hearts from healthy Sprague-Dawley rats and measured their function while they were perfused over four hours and under constant pressure in a Langendorff system [59]. In these studies, compared to controls exposure of hearts to a concentration of LT in the perfusion fluid comparable to ones shown to produce shock and lethality in the in vivo rat model $(50 \mathrm{ug} / \mathrm{mL})$, did not alter any parameter measured including among others: heart rate (HR), left ventricular developed pressure (LVDP), rate pressure product (RPP), $\mathrm{dP} / \mathrm{dt}$ max, and $\mathrm{dP} / \mathrm{dt}$ min. Only when the concentration of LT was increased to levels 10 -fold $(500 \mathrm{ug} / \mathrm{mL})$ greater than ones producing shock in vivo, were changes seen including decreases in HR, LVDP and $\mathrm{dP} / \mathrm{dt}$ max and increases in $\mathrm{dP} / \mathrm{dt}$ min (Figure 2). The relevance of these latter changes were unclear however since they were evident only with LT concentrations much greater than the doses employed in vivo. Furthermore, absence of changes in cardiac function with the lower LT concentration may have been due to inadequate observation time to see changes develop.

To explore this latter possibility further, we challenged Sprague-Dawley rats with a $24 \mathrm{~h}$ infusion of LT in doses that resulted in $30 \%$ lethality rates [60]. At 8, 24, or $48 \mathrm{~h}$ after the start of LT (or control infusion) animals were randomly selected and had echocardiography performed after which they were sacrificed and their hearts were isolated and perfused under constant pressure 
in the Langendorff system. On echocardiography, compared to controls, LT challenge decreased left ventricular ejection fraction (LVEF) at 8 and $48 \mathrm{~h}$ but increased it at $24 \mathrm{~h}$ in patterns that differed significantly over time. Lethal toxin also decreased calculated cardiac output (CO) across the three time points in an overall pattern that was significant. However, once hearts were isolated from animals and investigated independent of potential preload and afterload effects present in vivo, prior lethal LT challenge was not associated with significant differences in any parameter, including HR, LVDP, RPP, $\mathrm{dP} / \mathrm{dt} \max$, or $\mathrm{dP} / \mathrm{dt} \min$ at any time point compared to controls (Figure 3). Table 2 summarizes functional cardiac findings from the pre-clinical studies in lethal toxin challenged models.

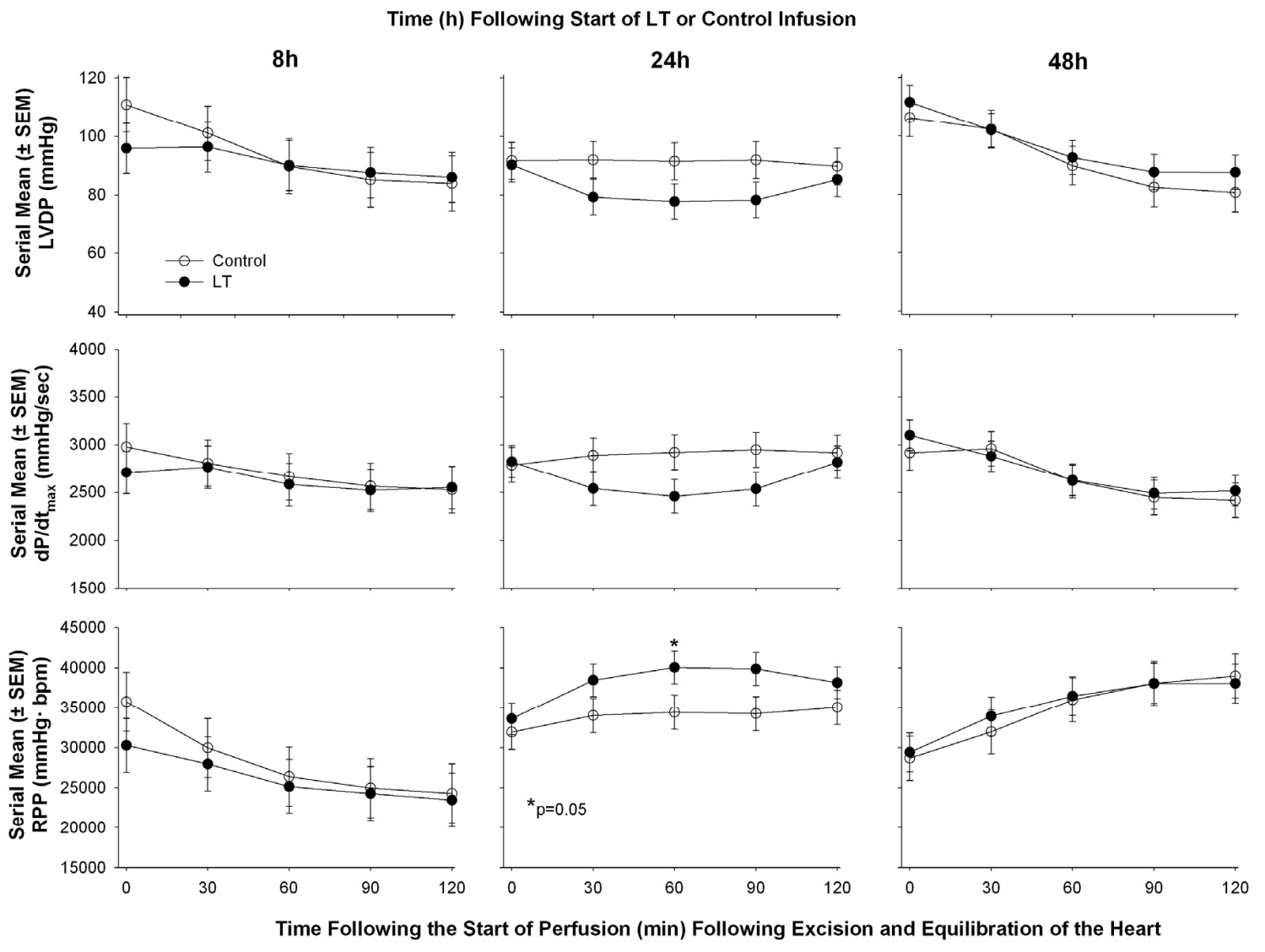

Figure 3. Serial mean $( \pm$ SEM) left ventricular developed pressure (LVDP), maximum rate of change in $\mathrm{LV}$ pressure during contraction $(\mathrm{dP} / \mathrm{dt} \max )$, and rate pressure product (RPP) in hearts excised from animals at either 8,24 , or $48 \mathrm{~h}$ after the initiation of an in vivo $24 \mathrm{~h}$ infusion of lethal toxin (LT) or protective antigen alone (control) and then perfused under constant pressure. The only significant difference $(p=0.05)$ that was noted between LT and control was a decrease in $\mathrm{dP} / \mathrm{dt}$ max at $60 \mathrm{~min}$ of perfusion. 
Table 2. Summary of functional cardiac findings from preclinical studies in lethal toxin challenged models.

\begin{tabular}{|c|c|c|c|c|}
\hline Publication & Subjects & $\begin{array}{l}\text { Route of Lethal } \\
\text { Toxin Exposure }\end{array}$ & $\begin{array}{c}\text { Functional } \\
\text { Measurement }\end{array}$ & Findings \\
\hline $\begin{array}{c}\text { Watson et al. } 2007 \\
\text { [13] }\end{array}$ & Sprague-Dawley rat & Intravenous bolus & Echocardiography & $\begin{array}{l}\text { - } 20 \% \text { increase in } \\
\text { LVAs and LVAd } \\
\text { within } 2 \mathrm{~h} \text {. Specific } \\
\text { LVEF measurements } \\
\text { not reported; } \\
\text {-Increase in Vp }\end{array}$ \\
\hline $\begin{array}{c}\text { Watson et al. } 2007 \\
\text { [52] }\end{array}$ & Sprague-Dawley rat & Intravenous bolus & Echocardiography & $\begin{array}{l}\text {-30\% reduction in } \\
\text { LVEF in } 11 / 14 \text { rats } \\
\text { surviving after } 48 \mathrm{~h} \\
\text { related to acute } \\
\text { increase in LVAs. No } \\
\text { increase in } \\
\text { LVAd noted; } \\
\text {-Decreased VCFC, } \\
\text { Decrease in Vp }\end{array}$ \\
\hline Cheng et al. 2007 [57] & Canine & Intravenous bolus & $\begin{array}{l}\text { Pressure-Volume } \\
\text { catheter }\end{array}$ & $\begin{array}{l}\text {-Significant LV } \\
\text { dysfunction starting } \\
\text { at } 6 \text { h with } \\
\text { development of heart } \\
\text { failure at } 96 \mathrm{~h} \text {; } \\
\text {-Decreases in LVEF, } \\
\text { stroke volume, } \\
\text { LVESP, contractility, } \\
\text { prolonged relaxation } \\
\text { time constant, } \\
\text { increases in LVEDP }\end{array}$ \\
\hline $\begin{array}{c}\text { Moayeri et al. } 2009 \\
{[14]}\end{array}$ & C57BL/6J mouse & Intravenous bolus & Echocardiography & $\begin{array}{l}\text {-Decreases in } \\
\text { ejection fraction and } \\
\text { fractional shortening } \\
\text { at } 24 \mathrm{~h} \text { after LT } \\
\text { challenge without } \\
\text { change in stroke } \\
\text { volume or CO }\end{array}$ \\
\hline $\begin{array}{c}\text { Sweeney et al. } 2010 \\
\text { [17] }\end{array}$ & Purpose-bred Beagle & Continuous infusion & $\begin{array}{c}\text { PA Catheter } \\
\text { Echocardiography }\end{array}$ & $\begin{array}{l}\text {-Low and high dose } \\
\text { (see section } 4 \text { ) of LT } \\
\text { caused progressive } \\
\text { declines }(15 \%-20 \%) \\
\text { in LVEF at } 72 \mathrm{~h} \text {; } \\
\text { - No significant } \\
\text { change in PAOP or } \\
\text { SVI with either dose } \\
\text { but CVP decreased } \\
\text { with high dose }\end{array}$ \\
\hline $\begin{array}{c}\text { Lawrence et al. } 2011 \\
\text { [20] }\end{array}$ & Dutch-belted rabbit & Intravenous bolus & Echocardiography & $\begin{array}{l}\text {-Serial echo } \\
\text { measurements at } 0 \text { to } \\
48 \mathrm{~h} \text { showed no } \\
\text { significant change in } \\
\text { LVAs or LVAd } \\
\text { despite elevated } \\
\text { markers of } \\
\text { myocardial injury }\end{array}$ \\
\hline Hicks et al. 2011 [59] & $\begin{array}{c}\text { Isolated } \\
\begin{array}{c}\text { Sprague-Dawley rat } \\
\text { heart }\end{array}\end{array}$ & $\begin{array}{l}\text { Continuous } \\
\text { non-recirculating } \\
\text { perfusion }\end{array}$ & $\begin{array}{c}\text { Ex-vivo Langendorff } \\
\text { Model }\end{array}$ & $\begin{array}{l}\text {-No change in LVDP, } \\
\mathrm{RPP} \text {, or dP/dt max at } \\
\text { a known lethal dose } \\
\text { of LT; } \\
\text {-A 10-fold increase in } \\
\text { the lethal dose } \\
\text { caused decreases in } \\
\text { all measured } \\
\text { parameters }\end{array}$ \\
\hline Liu et al. 2013 [10] & Mouse & Intraperitoneal & Echocardiography & $\begin{array}{l}\text {-Significant decrease } \\
\text { in EF at } 48 \mathrm{~h} \text { after LT } \\
\text { challenge }\end{array}$ \\
\hline
\end{tabular}


Table 2. Cont.

\begin{tabular}{|c|c|c|c|c|}
\hline Publication & Subjects & $\begin{array}{l}\text { Route of Lethal } \\
\text { Toxin Exposure }\end{array}$ & $\begin{array}{c}\text { Functional } \\
\text { Measurement }\end{array}$ & Findings \\
\hline $\begin{array}{c}\text { Golden et al. } 2013 \\
\text { [16] }\end{array}$ & Sprague-Dawley rat & Intravenous bolus & Echocardiography & $\begin{array}{l}\text {-Abnormal indices of } \\
\text { diastolic dysfunction } \\
\text { within } 2-8 \mathrm{~h} \\
\text { including prolonged } \\
\text { LV deceleration time, } \\
\text { elevated E/E' ratio, } \\
\text { left atrial chamber } \\
\text { enlargement and } \\
\text { pulmonary } \\
\text { regurgitation; } \\
\text {-No change in } \\
\text { EF noted }\end{array}$ \\
\hline Li et al. 2015 [60] & Sprague-Dawley rat & Continuous infusion & $\begin{array}{l}\text { Echocardiography } \\
\text { in vivo followed by ex } \\
\text { vivo Langendorff } \\
\text { Model }\end{array}$ & $\begin{array}{l}\text {-LT decreased CO } \\
\text { and decreased LVEF } \\
\text { at } 8 \text { and } 48 \mathrm{~h} \text { but } \\
\text { increased it at } 24 \mathrm{~h} \\
\text { measured with } \\
\text { cardiac echo; } \\
\text {-In isolated hearts } \\
\text { following in vivo } \\
\text { exposure to LT no } \\
\text { consistent change at } \\
8,24 \text {, or } 48 \mathrm{~h} \text { in } \mathrm{LVSP} \text {, } \\
\mathrm{LVDP}, \mathrm{RPP} \text {, or } \mathrm{dP} / \mathrm{dt} \\
\text { max or min }\end{array}$ \\
\hline
\end{tabular}

CO: Cardiac output, $\mathrm{dP} / \mathrm{dt}$ : Rate of change in LV pressure during contraction, LVDP: Left ventricular developed pressure $(L V D P=L V S P-L V E D P)$, LVEDP: Left ventricular end diastolic pressure, LVEF: Left ventricular ejection fraction, LVESP: Left ventricular end systolic pressure, LVSP: Left ventricular systolic pressure, LVAs: Left ventricular area in systole, LVAd: Left ventricular area in diastole, PAOP: Pulmonary artery occlusion pressure, RPP: Rate pressure product $(L V D P \times H R)$, SVI: Stroke volume index, VCFC: velocity of circumferential fiber shortening, Vp: velocity of propagation.

\section{Conclusions}

As recently noted, the mediators and mechanisms underlying hemodynamic instability during B. anthracis infection are multifactorial and complex [61]. Likely related to this complexity, findings from clinical reports in combination with in vivo, in vitro and ex vivo studies provide a mixed picture as to whether B. anthracis infection is associated with myocardial depression or whether LT itself can cause this depression directly and independent of its other systemic effects. Interestingly, in the one clinical report providing both echocardiography and pulmonary arterial catheter data in a patient requiring vasopressor therapy and who ultimately died, left ventricular dysfunction other than that related to a progressive pericardial effusion appeared minimal [18]. While data from echocardiography studies in other patients are more limited, several reports from patients with severe disease have also not been remarkable [19,37]. In those reports where dysfunction has been noted, whether this was related to prior disease in older patients or to infection itself is unclear since follow-up studies after resolution of infection were not provided. Comparison of animal studies with LT alone may be difficult to interpret based on the multiple factors that differed between them (e.g., differing species and models employed and methods of toxin administration) as well as the fact that many of these studies did not account for changes in preload and afterload with LT or with changes in pulmonary function. However, even in models accounting for such influence, the effects of LT on cardiac function have been variable.

In conclusion, if LT does contribute to shock during anthrax infection, presently available clinical data do not provide strong evidence that this compromise is related to direct myocardial depression. However, efforts should continue to be made to further understand the impact of LT on myocardial function in anthrax sepsis both clinically and in preclinical models. This question carries important 
implications not only for the conventional management of patients with anthrax infection and shock but also for the development of new and targeted therapies.

Author Contributions: D.A.S., H.S.-K., Y.L., L.O., K.E.R., X.C., and P.Q.E. drafted manuscript; D.A.S., X.C., and P.Q.E., prepared figures; D.A.S., X.C., and P.Q.E. edited and revised manuscript.

Conflicts of Interest: The authors declare no conflict of interest.

\section{References}

1. Jernigan, J.A.; Stephens, D.S.; Ashford, D.A.; Omenaca, C.; Topiel, M.S.; Galbraith, M.; Tapper, M.; Fisk, T.L.; Zaki, S.; Popovic, T.; et al. Bioterrorism-related inhalational anthrax: The first 10 cases reported in the united states. Emerg. Infect. Dis. 2001, 7, 933-944. [CrossRef] [PubMed]

2. Booth, M.; Donaldson, L.; Cui, X.; Sun, J.; Cole, S.; Dailsey, S.; Hart, A.; Johns, N.; McConnell, P.; McLennan, T.; et al. Confirmed bacillus anthracis infection among persons who inject drugs, scotland, 2009-2010. Emerg. Infect. Dis. 2014, 20, 1452-1463. [CrossRef] [PubMed]

3. Stevenson, E.K.; Rubenstein, A.R.; Radin, G.T.; Wiener, R.S.; Walkey, A.J. Two decades of mortality trends among patients with severe sepsis: A comparative meta-analysis. Crit. Care Med. 2014, 42, $625-631$. [CrossRef] [PubMed]

4. Angus, D.C.; van der Poll, T. Severe sepsis and septic shock. N. Engl. J. Med. 2013, 369, 840-851. [CrossRef] [PubMed]

5. Remy, K.E.; Qiu, P.; Li, Y.; Cui, X.; Eichacker, P.Q.B. Anthracis associated cardiovascular dysfunction and shock: The potential contribution of both non-toxin and toxin components. BMC Med. 2013, 11, 217. [CrossRef] [PubMed]

6. Rolando, M.; Stefani, C.; Flatau, G.; Auberger, P.; Mettouchi, A.; Mhlanga, M.; Rapp, U.; Galmiche, A.; Lemichez, E. Transcriptome dysregulation by anthrax lethal toxin plays a key role in induction of human endothelial cell cytotoxicity. Cell. Microbiol. 2010, 12, 891-905. [CrossRef] [PubMed]

7. Guichard, A.; McGillivray, S.M.; Cruz-Moreno, B.; van Sorge, N.M.; Nizet, V.; Bier, E. Anthrax toxins cooperatively inhibit endocytic recycling by the Rab11/Sec15 exocyst. Nature 2010, 467, 854-858. [CrossRef] [PubMed]

8. Warfel, J.M.; D'Agnillo, F. Anthrax lethal toxin-mediated disruption of endothelial VE-cadherin is attenuated by inhibition of the Rho-associated kinase pathway. Toxins 2011, 3, 1278-1293. [CrossRef] [PubMed]

9. Liu, S.; Moayeri, M.; Leppla, S.H. Anthrax lethal and edema toxins in anthrax pathogenesis. Trends Microbiol. 2014, 22, 317-325. [CrossRef] [PubMed]

10. Liu, S.; Zhang, Y.; Moayeri, M.; Liu, J.; Crown, D.; Fattah, R.J.; Wein, A.N.; Yu, Z.X.; Finkel, T.; Leppla, S.H. Key tissue targets responsible for anthrax-toxin-induced lethality. Nature 2013, 501, 63-68. [CrossRef] [PubMed]

11. Abramova, F.A.; Grinberg, L.M.; Yampolskaya, O.V.; Walker, D.H. Pathology of inhalational anthrax in 42 cases from the sverdlovsk outbreak of 1979. Proc. Natl. Acad. Sci. USA 1993, 90, 2291-2294. [CrossRef] [PubMed]

12. Grinberg, L.M.; Abramova, F.A.; Yampolskaya, O.V.; Walker, D.H.; Smith, J.H. Quantitative pathology of inhalational anthrax I: Quantitative microscopic findings. Mod. Pathol. 2001, 14, 482-495. [CrossRef] [PubMed]

13. Watson, L.E.; Kuo, S.R.; Katki, K.; Dang, T.; Park, S.K.; Dostal, D.E.; Tang, W.J.; Leppla, S.H.; Frankel, A.E. Anthrax toxins induce shock in rats by depressed cardiac ventricular function. PLoS ONE 2007, 2, e466. [CrossRef] [PubMed]

14. Moayeri, M.; Crown, D.; Dorward, D.W.; Gardner, D.; Ward, J.M.; Li, Y.; Cui, X.; Eichacker, P.; Leppla, S.H. The heart is an early target of anthrax lethal toxin in mice: A protective role for neuronal nitric oxide synthase (nNOS). PLoS Pathog. 2009, 5. [CrossRef] [PubMed]

15. Kandadi, M.R.; Frankel, A.E.; Ren, J. Toll-like receptor 4 knockout protects against anthrax lethal toxin-induced cardiac contractile dysfunction: Role of autophagy. Br. J. Pharmacol. 2012, 167, 612-626. [CrossRef] [PubMed] 
16. Golden, H.B.; Watson, L.E.; Nizamutdinov, D.; Feng, H.; Gerilechaogetu, F.; Lal, H.; Verma, S.K.; Mukhopadhyay, S.; Foster, D.M.; Dillmann, W.H.; et al. Anthrax lethal toxin induces acute diastolic dysfunction in rats through disruption of the phospholamban signaling network. Int. J. Cardiol. 2013, 168, 3884-3895. [CrossRef] [PubMed]

17. Sweeney, D.A.; Cui, X.; Solomon, S.B.; Vitberg, D.A.; Migone, T.S.; Scher, D.; Danner, R.L.; Natanson, C.; Subramanian, G.M.; Eichacker, P.Q. Anthrax lethal and edema toxins produce different patterns of cardiovascular and renal dysfunction and synergistically decrease survival in canines. J. Infect. Dis. 2010, 202, 1885-1896. [CrossRef] [PubMed]

18. Mina, B.; Dym, J.P.; Kuepper, F.; Tso, R.; Arrastia, C.; Kaplounova, I.; Faraj, H.; Kwapniewski, A.; Krol, C.M.; Grosser, M.; et al. Fatal inhalational anthrax with unknown source of exposure in a 61-year-old woman in new york city. JAMA 2002, 287, 858-862. [CrossRef] [PubMed]

19. Russell, L.; Pedersen, M.; Jensen, A.V.; Soes, L.M.; Hansen, A.B. Two anthrax cases with soft tissue infection, severe oedema and sepsis in danish heroin users. BMC Infect. Dis. 2013, 13, 408. [CrossRef] [PubMed]

20. Lawrence, W.S.; Marshall, J.R.; Zavala, D.L.; Weaver, L.E.; Baze, W.B.; Moen, S.T.; Whorton, E.B.; Gourley, R.L.; Peterson, J.W. Hemodynamic effects of anthrax toxins in the rabbit model and the cardiac pathology induced by lethal toxin. Toxins 2011, 3, 721-736. [CrossRef] [PubMed]

21. Young, J.A.; Collier, R.J. Anthrax toxin: Receptor binding, internalization, pore formation, and translocation. Annu. Rev. Biochem. 2007, 76, 243-265. [CrossRef] [PubMed]

22. Bromberg-White, J.; Lee, C.S.; Duesbery, N. Consequences and utility of the zinc-dependent metalloprotease activity of anthrax lethal toxin. Toxins 2010, 2, 1038-1053. [CrossRef] [PubMed]

23. Moayeri, M.; Sastalla, I.; Leppla, S.H. Anthrax and the inflammasome. Microbes Infect. 2012, 14, 392-400. [CrossRef] [PubMed]

24. Rolli, J.; Rosenblatt-Velin, N.; Li, J.; Loukili, N.; Levrand, S.; Pacher, P.; Waeber, B.; Feihl, F.; Ruchat, P.; Liaudet, L. Bacterial flagellin triggers cardiac innate immune responses and acute contractile dysfunction. PLoS ONE 2010, 5. [CrossRef] [PubMed]

25. Zhang, W.; Xu, X.; Kao, R.; Mele, T.; Kvietys, P.; Martin, C.M.; Rui, T. Cardiac fibroblasts contribute to myocardial dysfunction in mice with sepsis: The role of NLRP3 inflammasome activation. PLoS ONE 2014, 9. [CrossRef] [PubMed]

26. Natanson, C.; Danner, R.L.; Elin, R.J.; Hosseini, J.M.; Peart, K.W.; Banks, S.M.; MacVittie, T.J.; Walker, R.I.; Parrillo, J.E. Role of endotoxemia in cardiovascular dysfunction and mortality. Escherichia coli and staphylococcus aureus challenges in a canine model of human septic shock. J. Clin. Invest. 1989, 83, $243-251$.

27. Guarner, J.; Jernigan, J.A.; Shieh, W.J.; Tatti, K.; Flannagan, L.M.; Stephens, D.S.; Popovic, T.; Ashford, D.A.; Perkins, B.A.; Zaki, S.R. Pathology and pathogenesis of bioterrorism-related inhalational anthrax. Am. J. Pathol. 2003, 163, 701-709. [CrossRef]

28. Bush, L.M.; Abrams, B.H.; Beall, A.; Johnson, C.C. Index case of fatal inhalational anthrax due to bioterrorism in the united states. N. Engl. J. Med. 2001, 345, 1607-1610. [CrossRef] [PubMed]

29. Borio, L.; Frank, D.; Mani, V.; Chiriboga, C.; Pollanen, M.; Ripple, M.; Ali, S.; DiAngelo, C.; Lee, J.; Arden, J.; et al. Death due to bioterrorism-related inhalational anthrax: Report of 2 patients. JAMA 2001, 286, 2554-2559. [CrossRef] [PubMed]

30. Quintiliani, R., Jr.; Quintiliani, R. Fatal case of inhalational anthrax mimicking intra-abdominal sepsis. Conn. Med. 2002, 66, 261-267. [PubMed]

31. Barakat, L.A.; Quentzel, H.L.; Jernigan, J.A.; Kirschke, D.L.; Griffith, K.; Spear, S.M.; Kelley, K.; Barden, D.; Mayo, D.; Stephens, D.S.; et al. Fatal inhalational anthrax in a 94-year-old connecticut woman. JAMA 2002, 287, 863-868. [CrossRef] [PubMed]

32. Albrink, W.S.; Brooks, S.M.; Biron, R.E.; Kopel, M. Human inhalation anthrax. A report of three fatal cases. Am. J. Pathol. 1960, 36, 457-471. [PubMed]

33. Tabei, S.Z.; Amin, A.; Mowla, A.; Nabavizadeh, S.A.; Razmkon, A. Anthrax: Pathological aspects in autopsy cases in shiraz, islamic republic of iran, 1960-2001. East. Mediterr. Health J. 2004, 10, 27-36. [PubMed]

34. Berger, T.; Kassirer, M.; Aran, A.A. Injectional anthrax-New presentation of an old disease. Euro. Surveill. 2014, 19. [CrossRef] 
35. Walsh, J.J.; Pesik, N.; Quinn, C.P.; Urdaneta, V.; Dykewicz, C.A.; Boyer, A.E.; Guarner, J.; Wilkins, P.; Norville, K.J.; Barr, J.R.; et al. A case of naturally acquired inhalation anthrax: Clinical care and analyses of anti-protective antigen immunoglobulin $\mathrm{g}$ and lethal factor. Clin. Infect. Dis. 2007, 44, 968-971. [CrossRef] [PubMed]

36. Anaraki, S.; Addiman, S.; Nixon, G.; Krahe, D.; Ghosh, R.; Brooks, T.; Lloyd, G.; Spencer, R.; Walsh, A.; McCloskey, B.; et al. Investigations and control measures following a case of inhalation anthrax in East London in a drum maker and drummer, October 2008. Euro. Surveill. 2008, 13, 11-13.

37. Klempner, M.S.; Talbot, E.A.; Lee, S.I.; Zaki, S.; Ferraro, M.J. Case records of the massachusetts general hospital. Case 25-2010. A 24-year-old woman with abdominal pain and shock. N. Engl. J. Med. 2010, 363, 766-777. [PubMed]

38. Sprenkle, M.D.; Griffith, J.; Marinelli, W.; Boyer, A.E.; Quinn, C.P.; Pesik, N.T.; Hoffmaster, A.; Keenan, J.; Juni, B.A.; Blaney, D.D. Lethal factor and anti-protective antigen IGG levels associated with inhalation anthrax, minnesota, USA. Emerg. Infect. Dis. 2014, 20, 310-314. [CrossRef] [PubMed]

39. Babamahmoodi, F.; Aghabarari, F.; Arjmand, A.; Ashrafi, G.H. Three rare cases of anthrax arising from the same source. J. Infect. 2006, 53, e175-e179. [CrossRef] [PubMed]

40. Doganay, M.; Metan, G.; Alp, E. A review of cutaneous anthrax and its outcome. J. Infect. Public Health 2010, 3, 98-105. [CrossRef] [PubMed]

41. Popescu, R.; Pistol, A.; Miltaru, L.; Caplan, D.; Cucuiu, R.; Popovici, F. Two cases of infection with bacillus anthracis, Romania, October 2011. Euro. Surveill. 2011, 16, 733-735.

42. Powell, A.G.; Crozier, J.E.; Hodgson, H.; Galloway, D.J. A case of septicaemic anthrax in an intravenous drug user. BMC Infect. Dis. 2011, 11, 21. [CrossRef] [PubMed]

43. Grunow, R.; Verbeek, L.; Jacob, D.; Holzmann, T.; Birkenfeld, G.; Wiens, D.; von Eichel-Streiber, L.; Grass, G.; Reischl, U. Injection anthrax-A new outbreak in heroin users. Dtsch. Arztebl. Int. 2012, 109, 843-848. [PubMed]

44. Mayer, T.A.; Bersoff-Matcha, S.; Murphy, C.; Earls, J.; Harper, S.; Pauze, D.; Nguyen, M.; Rosenthal, J.; Cerva, D., Jr.; Druckenbrod, G.; et al. Clinical presentation of inhalational anthrax following bioterrorism exposure: Report of 2 surviving patients. JAMA 2001, 286, 2549-2553. [CrossRef] [PubMed]

45. Smith, H.; Keppie, J. Observations on experimental anthrax; demonstration of a specific lethal factor produced in vivo by bacillus anthracis. Nature 1954, 173, 869-870. [CrossRef] [PubMed]

46. Smith, H.; Keppie, J.; Stanley, J.L.; Harris-Smith, P.W. The chemical basis of the virulence of bacillus anthracis. IV. Secondary shock as the major factor in death of guinea-pigs from anthrax. Br. J. Exp. Pathol. 1955, 36, 323-335. [PubMed]

47. Sherer, K.; Li, Y.; Cui, X.; Eichacker, P.Q. Lethal and edema toxins in the pathogenesis of bacillus anthracis septic shock: Implications for therapy. Am. J. Respir. Crit. Care Med. 2007, 175, 211-221. [CrossRef] [PubMed]

48. Moayeri, M.; Leppla, S.H. Cellular and systemic effects of anthrax lethal toxin and edema toxin. Mol. Aspects Med. 2009, 30, 439-455. [CrossRef] [PubMed]

49. Moayeri, M.; Haines, D.; Young, H.A.; Leppla, S.H. Bacillus anthracis lethal toxin induces TNF-alpha-independent hypoxia-mediated toxicity in mice. J. Clin. Invest. 2003, 112, 670-682. [CrossRef] [PubMed]

50. Cui, X.; Moayeri, M.; Li, Y.; Li, X.; Haley, M.; Fitz, Y.; Correa-Araujo, R.; Banks, S.M.; Leppla, S.H.; Eichacker, P.Q. Lethality during continuous anthrax lethal toxin infusion is associated with circulatory shock but not inflammatory cytokine or nitric oxide release in rats. Am. J. Physiol. Regul. Integr. Comp. Physiol. 2004, 286, R699-R709. [CrossRef] [PubMed]

51. Kuo, S.R.; Willingham, M.C.; Bour, S.H.; Andreas, E.A.; Park, S.K.; Jackson, C.; Duesbery, N.S.; Leppla, S.H.; Tang, W.J.; Frankel, A.E. Anthrax toxin-induced shock in rats is associated with pulmonary edema and hemorrhage. Microb. Pathog. 2008, 44, 467-472. [CrossRef] [PubMed]

52. Watson, L.E.; Mock, J.; Lal, H.; Lu, G.; Bourdeau, R.W.; Tang, W.J.; Leppla, S.H.; Dostal, D.E.; Frankel, A.E. Lethal and edema toxins of anthrax induce distinct hemodynamic dysfunction. Front. Biosci. 2007, 12, 4670-4675. [CrossRef] [PubMed]

53. Kandadi, M.R.; Hua, Y.; Ma, H.; Li, Q.; Kuo, S.R.; Frankel, A.E.; Ren, J. Anthrax lethal toxin suppresses murine cardiomyocyte contractile function and intracellular $\mathrm{Ca}^{2+}$ handling via a nadph oxidase-dependent mechanism. PLoS ONE 2010, 5. [CrossRef] [PubMed] 
54. Kandadi, M.R.; Yu, X.; Frankel, A.E.; Ren, J. Cardiac-specific catalase overexpression rescues anthrax lethal toxin-induced cardiac contractile dysfunction: Role of oxidative stress and autophagy. BMC Med. 2012, 10. [CrossRef] [PubMed]

55. Golden, H.B.; Watson, L.E.; Lal, H.; Verma, S.K.; Foster, D.M.; Kuo, S.R.; Sharma, A.; Frankel, A.; Dostal, D.E. Anthrax toxin: Pathologic effects on the cardiovascular system. Front. Biosci (Landmark Ed.) 2009, 14, 2335-2357. [CrossRef] [PubMed]

56. Frankel, A.E.; Kuo, S.R.; Dostal, D.; Watson, L.; Duesbery, N.S.; Cheng, C.P.; Cheng, H.J.; Leppla, S.H. Pathophysiology of anthrax. Front. Biosci. (Landmark Ed.) 2009, 14, 4516-4524. [CrossRef] [PubMed]

57. Cheng, C.-P.; Masutani, S.; Cheng, H.-J.; Cross, M.; Zhang, C.-X.; Zhou, P.; Cann, J.; Cline, J.M.; Little, W.C.; Kuo, S.-R.; et al. Progressive left ventricle, myocyte dysfunction, and heart failure in the lethality of anthrax toxin in conscious dogs. Circulation 2007, 116, 758.

58. Barochia, A.V.; Cui, X.; Sun, J.; Li, Y.; Solomon, S.B.; Migone, T.S.; Subramanian, G.M.; Bolmer, S.D.; Eichacker, P.Q. Protective antigen antibody augments hemodynamic support in anthrax lethal toxin shock in canines. J. Infect. Dis. 2012, 205, 818-829. [CrossRef] [PubMed]

59. Hicks, C.W.; Li, Y.; Okugawa, S.; Solomon, S.B.; Moayeri, M.; Leppla, S.H.; Mohanty, A.; Subramanian, G.M.; Mignone, T.S.; Fitz, Y.; et al. Anthrax edema toxin has camp-mediated stimulatory effects and high-dose lethal toxin has depressant effects in an isolated perfused rat heart model. Am. J. Physiol. Heart Circ. Physiol. 2011, 300, H1108-H1118. [CrossRef] [PubMed]

60. Li, Y.; Abu-Asab, M.; Su, J.; Qiu, P.; Feng, J.; Ohanjanian, L.; Kumar, H.S.; Fitz, Y.; Eichacker, P.Q.; Cui, X. Bacillus anthracis edema but not lethal toxin challenge in rats is associated with depressed myocardial function in hearts isolated and tested in a langendorff system. Am. J. Physiol. Heart Circ. Physiol. 2015, 308, H1592-H1602. [CrossRef] [PubMed]

61. Brojatsch, J.; Casadevall, A.; Goldman, D.L. Molecular determinants for a cardiovascular collapse in anthrax. Front. Biosci. (Elite Ed.) 2014, 6, 139-147. [CrossRef] [PubMed]

(C) 2015 by the authors; licensee MDPI, Basel, Switzerland. This article is an open access article distributed under the terms and conditions of the Creative Commons by Attribution (CC-BY) license (http://creativecommons.org/licenses/by/4.0/). 